\title{
Participatory perspectives
}

HE films considered in this final chapter were based on a participatory
praxis and involved an extended period of ethnographic fieldwork. They were all made in a cultural environment that differed significantly from the film-maker's own, thereby raising certain questions - some intellectual, others ethical - that are not so starkly posed when film-maker, subjects and audience all inhabit much the same cultural universe. As authored works of cinema, they all go beyond observation in the sense that the relationship between film-maker and subjects, far from being obscured or ignored, is central to the process of production and is inscribed, in varying degrees, in the filmic text itself. In this sense, they might be considered as examples of what Faye Ginsburg has recently termed 'relational documentary'. However, there are also a number of significant differences between them regarding the precise form in which this relationship is conducted and presented stylistically. As such, I offer them here as examples of a range of possible 'ways of doing' that - among many others - may provide the basis for taking ethnographic film-making into the future.

\section{PARTICIPATORY FILM-MAKING AS POLITICAL ENGAGEMENT: TraCKS ACROSS SAND AS 'A STORY OF OUR TIMES'}

Shot over a twelve-year period between 1996 and 2008, and finally released in 20I2, Tracks Across Sand is a series of films produced under the direction of the anthropologist Hugh Brody. It traces the historical background, the complex preparatory processes and the aftermath of the land restitution claim that, in I999, resulted in the $\neq$ Khomani San of the Southern Kalahari in South Africa being awarded formal title to some 65,00o hectares of land in and around the Kgalagadi National Park in the Northern Cape district, close to the frontiers with Namibia and Botswana. ${ }^{2}$

There are seventeen films in the series, of very variable lengths: the shortest is no longer than a minute, the longest is 52 minutes. All of them 
are distributed on a single DVD of almost four hours duration. Even this is only a fraction of the 135 hours of rushes that was available to Brody when editing, all of which have been stored in an archive where they will be available to future generations. Resonating with the circumstances of many indigenous peoples across the world, the story that Tracks Across Sand tells - of loss, restitution, followed by a realisation that the recuperation of land is not a panacea for all the ills suffered by an indigenous people - is one that serves, as an intertitle declares at the end of the introductory film, as 'a story of our times'.

The origins of the $\neq$ Khomani San land restitution project lay in a chance meeting in I992, at a private game reserve not far from Cape Town, between Roger Chennells, a white South African human rights lawyer and Dawid Kruiper, a San elder, who at that time was scratching out a living selling handicrafts and posing for tourist photographs on the periphery of the game reserve. Kruiper told Chennells the story of his group's eviction from their ancestral lands around the Kgalagadi Park (then still called the Gemsbok National Park), which lay some 500 miles to the north of the place where the two men met. These evictions had mostly occurred in two separate waves, one in the I930s, and then again later in the I970s. Chennells realised that the legal instruments introduced by the African National Congress as part of the new post-apartheid constitution, which overturned the discriminatory Native Lands Act of I9I3, could provide the vehicle for making a claim for the restitution of the $\neq$ Khomani San lands that did not involve raising questions of aboriginal title, which in a South African context would have been highly problematic. Accordingly, encouraged and supported professionally by Chennells, Kruiper and his family entered a formal claim for restitution in 1994 .

In the absence of any written evidence of the $\neq$ Khomani San's prior occupancy, the Kruiper land claim could have been subject to legal challenge. In order to combat this possibility, a cultural mapping programme was initiated in I996. This was designed to establish, mostly on the basis of interviews with $\neq$ Khomani San elders, not only the material facts of their use of their ancestral lands for subsistence purposes, but also their cultural appropriation of these lands in the form of the naming of landmarks, burial sites, stories of childhood experiences and other indicators of cultural significance. One of those involved in the project was Nigel Crawhall, a sociolinguist working with the South African National Language Project. As Crawhall had studied in Canada, he knew of Brody's work on cultural mapping in connection with the land rights claims of the Canadian Inuit in the I970s. It was on these grounds, rather than as a film-maker, that Brody was initially invited to take part in the project.

On the Tracks Across Sand DVD, the main body of the material is framed by the two longest films: an Overture of 30 minutes that provides an overview 
of the whole process and an Aftermath of 52 minutes which considers the general circumstances of the $\neq$ Khomani $S a n$ in 2008 , nine years after they had been awarded the land title. Lying between these two films is a series of much shorter films that cover the cultural mapping process. Following Aftermath, there is a sort of epilogue of five short interviews with the non-San involved in the project. The interviewees include Grace Humphries, the director of an NGO that supports the San, Levi Namaseb, a Namibian linguist who participated in the cultural mapping, as well as Chennells, Crawhall and Brody himself. Finally, the DVD offers a gallery of portraits of all the principal protagonists of the films and copies of the geographical maps that arose from the cultural mapping process.

Shortly after he became involved in the project, Brody realised that the process that he had developed with the Inuit would have to be accommodated in order to meet the very different circumstances of the $\neq$ Khomani San. While the Inuit were still living on their lands when Brody worked with them in the I970s, the $\neq$ Khomani San had been exiled from their ancestral territories for as long as two generations, and were now mostly living in squatter camps in urban or peri-urban locations, scattered across South Africa. Therefore, as well as recording accounts of traditional resource use, Brody and his colleagues also developed what they called 'time-lines' with their San collaborators, that is, accounts of the history of their dispossession, first in the I93Os and then again in the I970s. These are presented, sometimes supported by archival photographs, in three short films under the general title 'Evictions'.

Another element that took on increasing significance as the cultural mapping proceeded, and which is the subject of two short films on the DVD, was the recovery of $\mathrm{N} / \mathrm{uu}$, the original language of the $\neq$ Khomani San (and one of some fourteen distinct languages originally spoken by San populations across southern Africa). Following their eviction from the Southern Kalahari and in the face of intense disdain for their traditional culture on the part of the surrounding population, many $\neq$ Khomani San had abandoned their language and subsequent generations had grown up speaking only Afrikaans: so much so that in I970, N/uu was officially declared to be extinct. However, the researchers working on the cultural mapping project soon began to discover that a number of elderly people were still able to speak N/uu: by the end of the project, they had discovered some 28 speakers of the language, albeit dispersed over very large distances.

In many instances, it was only when these elderly San spoke N/uu for the purposes of the project that their children or grandchildren became aware that they still could speak it. One of the most moving sequences in the whole of the Tracks Across Sand DVD is some amateurish video footage of the occasion when three elderly sisters, all speakers of $\mathrm{N} / \mathrm{uu}$, surrounded 
by marvelling members of their respective families and two equally entranced sociolinguists, identify an audio recording made in the I930s as being in $\mathrm{N} / \mathrm{uu}$ and offer a translation. It transpires that the recording concerns a traditional custom practised when a bride-to-be was in seclusion prior to her marriage: this involved setting aside a choice antelope rib which was then roasted when she finally emerged to be married. Inspired by the memory of those distant marriage feasts, the three elderly sisters then break into spontaneous singing and rhythmic clapping.

At various points, San elders express the pious hope that young people will now learn the $\mathrm{N} / \mathrm{uu}$ language again, though the films make clear that it is very unlikely that this will ever happen in sufficient numbers for $\mathrm{N} / \mathrm{uu}$ to replace Afrikaans as the lingua franca of the $\neq$ Khomani San. But the recovery of the language served a more general purpose of the cultural mapping project, namely, to instil a sense of pride in a collective identity among families that, since the evictions, had been dispersed and disconnected.

This was a central objective of other aspects of the project too, such as the working out of genealogies, which is the subject of one film, and of the recording of traditional ideas about the use and significance of features of the natural environment of the southern Kalahari, which is a theme that crops up in various forms through a number of the films. In one sequence, a man shows how he reads game animal tracks, in another an elderly woman recounts how ostrich eggs may be used as water carriers, while in a further series of very short films, anecdotes are told about particular trees: at one, an unrequited lover tried to hang himself but was saved by his father, while the branch of another tree served as the back of an imaginary donkey for a group of children (figure I6.I). A particularly moving sequence shows four elderly women scattering sand on what might appear to an outsider to be an unexceptional patch of desert scrub. This, the women reveal, is the burial place of their parents and grandparents. One of them says that she feels great pride to be back, looking again at the place where she buried her mother but from which she had been exiled for many years.

The most challenging film in the series to edit would surely have been Aftermath, the longest film and the one that presents $\neq$ Khomani San life nine years after the settlement of the land claim. For, as an intertitle dramatically asserts midway through the film, 'The claim may have brought justice, but it could not ensure well-being.'The cultural mapping films tell a feel-good story, in which it is relatively easy to distinguish the good from the bad. But this is not the case with Aftermath, which is heavily laden with ambiguities. For the euphoria of the day when none other than President-elect Thabo Mbeki came in a helicopter to present the title to the San, bringing with him the first, desperately-wished-for rains for many years, was soon to be replaced by tension and discord. 

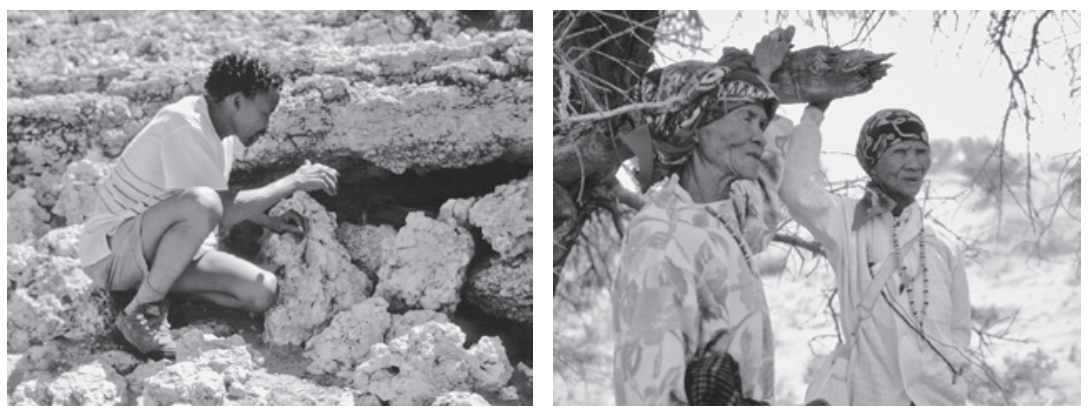

I6. I Cultural mapping in Tracks Across Sand (20I2). Left, Dawid Kruiper indicates the site of a beehive where his family gathered honey in the I930s; right, /Una and her sister Keis identify the branch that broke as they swung on it as children.

In effect, the land claim had physically gathered together in the Southern Kalahari a group of people who may have shared historical roots but who were in no sense a community. As a result, there was intense rivalry between different families for control over the resources that the government had made available along with the acknowledgement of the land claim. These resources were frequently squandered, though it was often not clear whether this was due to simple mismanagement or corruption.

Moreover, although the claim had established San rights over a large amount of land, it did little to address the fundamental issue of poverty. The San could now hunt and gather as their ancestors had done, but that was no longer sufficient to ensure a sense of material well-being, particularly for younger people. The isolation of the Southern Kalahari meant that the opportunities to generate a cash income were few and the provision of health and educational services was even more sporadic than it had been in the marginal shanty towns where the San had previously lived. Even drinking water was in short supply.

Although Aftermath considers the many positive aspects of the new circumstances of the $\neq$ Khomani San, it does not shy away from the fact that there have also been many social difficulties in the post-claim period. As the San themselves relate, there have been a disturbing number of cases of murder and rape while alcoholism has also been a widespread problem. The film includes a harrowing sequence in a liquor store and interviews two blind-drunk young men, continuing even after an older San man pleads with the film-makers to stop as it would make for bad publicity.

A stern critic might argue that Aftermath does not directly confront an issue that emerges strongly in some textual accounts of the $\neq$ Khomani San land claim settlement. These suggest that the $\neq$ Khomani San were caught 
in the same double-bind as the San of John Marshall's films in Namibia, that is, the fundamental contradiction inherent in the fact that while both the original land claim and the subsequent funding from the government and development aid donors were based on the presumption that the San wished to continue indefinitely with their traditional way of life, the harsh reality was that this was simply no longer viable, economically or socially. The only immediately practical way for the $\neq$ Khomani San to escape from this double-bind was to eke out a meagre income from enacting a pathetic simulacrum of their traditional way of life for tourists, selling handicrafts and giving lessons in animal tracking to outsiders who would never use these skills for real. While some $\neq$ Khomani San, including the original claimant Dawid Kruiper, were prepared to take this route, others wanted to introduce commercial livestock farming onto the land (goats and sheep rather than cattle). But this would not only have threatened the continuation of the hunting and gathering way of life on which the original land claim had been built, but would also have undermined the political authority of Kriuper and his family. ${ }^{3}$

Taken as a whole, Tracks Across Sand represents an excellent example of how an inter-related group of films may be used to explore a complex social and historical process in an ethnographic manner. Each of the seventeen films in the collection, regardless of length, has been carefully conceived, shot and edited, and has its own intrinsic narrative. Moreover, the collection as a whole has been structured, with the various different aspects of the land claim presented systematically in a series of films that are self-contained but which circle around the same themes. A number of key sequences recur time and again, in the manner of musical leitmotifs, while almost the entirety of the sequences that make up the opening film of the collection reappear again in later individual films, usually at greater length. It is therefore entirely appropriate that this opening film should have been dubbed Overture, even if at first sight this term might strike some viewers as somewhat grandiose.

According to the criteria proposed in this book, one would have no hesitation in qualifying Tracks Across Sand as an ethnographic work. Yet, in practical film-making terms, the sequences in the collection that could be described as observational are relatively few: there is a fine observational scene in which a group of San pack up their personal effects on the edge of a small town and head off to the ancestral lands, and there are also a number of observational scenes of children, and even adults, playing in the sand dunes once they arrive. But these are the exceptions that prove the general rule. Instead, 'talking heads' predominate throughout the collection. In this regard, Tracks Across Sand is markedly different in stylistic terms to Brody's own highly observational early film, Eskimos of Pond Inlet: The People's Land, discussed in Chapter II. But different circumstances call for 
different film-making praxes: the Inuit were still living on their lands, while the $\neq$ Khomani San were often recalling a world that no longer existed, even if they hoped, one day, to recreate it.

Tracks Across Sand not only contradicts the common assumption that in order to be ethnographic, a film has to be observational but it also gives the lie to the idea that films dominated by the spoken word cannot have a sensorial quality. Not only is the cinematography and soundtrack of these films of an exceptionally high standard, communicating a strong sense of place, but one cannot help but be moved by the eloquence and sheer poetry of the oral testimonies offered by the elderly San interlocutors. Rather than written documents, physical structures or monuments, it is these oral testimonies that communicate the San's continuing deep emotional connection to their ancestral lands, despite two generations of absence.

\section{PARTiCIPATORY FILM-MAKING AS ETHNOFICTION: TRANSFICTION}

If Tracks Across Sand contradicts the idea that in order to be ethnographic, it is necessary for a film to be observational, the next example of participatory film-making represents a challenge to the notion that an ethnographic film necessarily takes the form of a factual documentary.

Of course, this challenge is nothing new, since it was laid down by Jean Rouch as long ago as the I950s when he began working on a series of films in West Africa that involved an innovative blend of fact and fiction, including such well-known works as Jaguar (1957-7I) and Moi, un Noir (I960). Rouch himself never formulated a systematic methodology for this genre of film-making, which would eventually come to be known as 'ethnofiction' by third parties. (He himself preferred the term 'science fiction', a sort of pun based on the fact that in French, the term 'science' covers not just the natural sciences but also the social sciences, including ethnography.) For present purposes, one could say that the essential defining features of 'ethnofiction' include, first, the anchoring of the film in extended ethnographic field research and second, close collaboration between filmmaker and subjects in the performance of a series of spontaneous improvisations, albeit within the framework of a story that is loosely agreed upon beforehand though subject to constant revision as the filming proceeds. ${ }^{4}$

Rouch first developed the ethnofictional format as a way to reach those parts of human experience that neither written texts, nor more conventional documentary film-making were capable of reaching. In line with his abiding interest in Surrealism, the otherwise unreachable realm that Rouch himself sought to access through ethnofiction was his subjects' fantasies, dreams and imaginaries, which he believed would only emerge when the subjects were 
invited to improvise their everyday lives for a camera. But while this is one way of using the ethnofiction format, it can also be used as a means of representing more mundane aspects of subjects' everyday lives that would otherwise be impossible to show for ethical or logistical reasons.

It is now more than sixty years since Rouch made his first ethnofictions, and in the interim there have been relatively few attempts to emulate his works in this particular genre. I would surmise that this is because the successful production of an ethnofiction requires an unusual combination of skills and circumstances. These include an ethnographic researcher with a developed sense of dramaturgy and the cinematographic skills to match, as well as a group of subjects with whom the researcher has not only developed deep bonds of trust, but who also have at least a performative disposition that allows them to throw themselves with conviction into improvising the roles required for the film.

It was certainly a fortuitous coming together of this set of circumstances that allowed Transfiction to be made. This work, which was inspired by a combination of Rouch's ethnofictional practice and the politically oriented applied theatre of the Brazilian dramaturge, Augusto Boal, concerns the life of transgendered people in São Paulo, the largest city in Brazil. It was directed by Johannes Sjöberg, who is Swedish in origin and who is now a member of staff of the Drama department at the University of Manchester. In addition to holding academic qualifications in both dramatic arts and anthropology, Sjöberg has also had considerable acting experience outside a strictly academic environment. At time that he made Transfiction, he was a doctoral student in Applied Theatre, though he was also attached to the Social Anthropology department at Manchester. The film was made in the course of some fifteen months of ethnographic field research carried out in 2005-6 with the transgendered community in São Paulo, in particular with those associated with Os Satyros, a bohemian theatre in the centre of the city. In the classical Rouchian manner, Sjöberg himself acted as both cameraman and director, while the sound was taken by a local person. ${ }^{5}$

Transfiction has a running time of 57 minutes and was first released in 2007. The central narrative is built around two male-to-female transgendered characters: Zilda, who makes a living as a sex worker, and Meg, a hairdresser who works in a beauty salon. These characters were respectively played by Bibi Meirelles and Fabia Mirassos, both of whom were themselves transgendered. There was also a continuity between their real-life professions and those of the characters in the film: Bibi had worked as a transgendered sex worker in the past and was proud of having done so, while Fabia did indeed make a living as a hairdresser. Although Bibi and Fabia were friends in real life, there were also significant differences between them. Most obviously, Bibi was ten years older and whereas Fabia could easily pass herself off as a highly attractive woman, Bibi's feminity was less immediately 


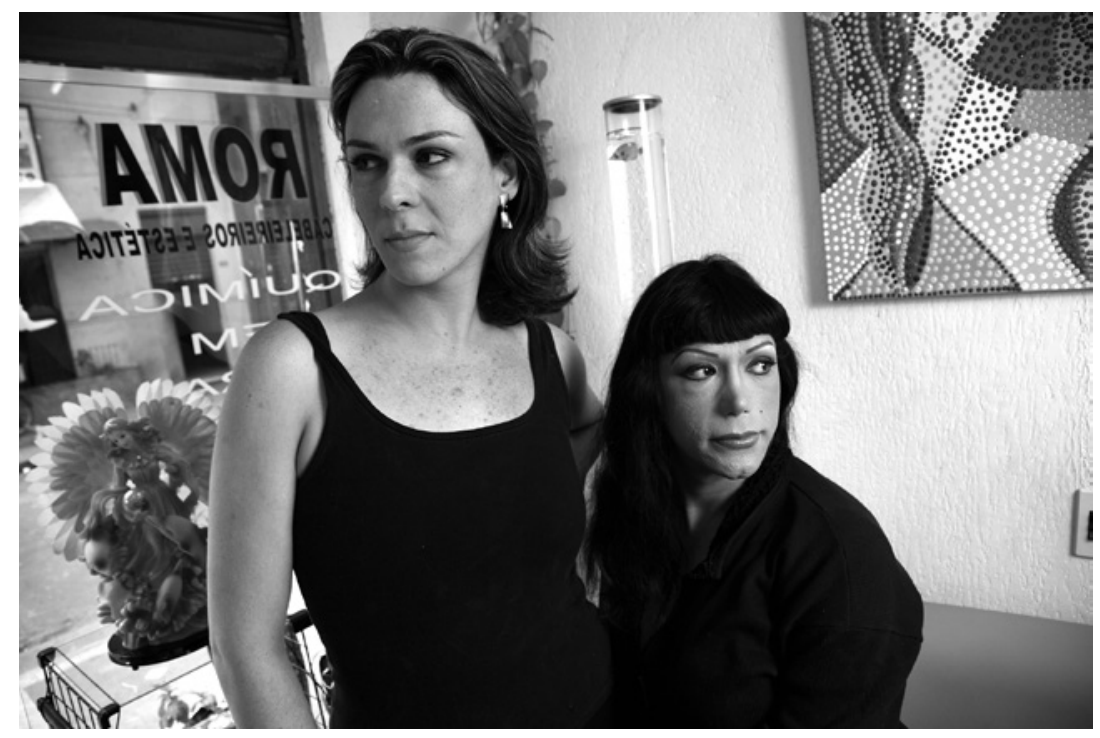

I6.2 Ethnofiction in Transfiction (2007). Fabia Mirassos, left, who plays Meg, and Bibi Meirelles, who plays Zilda, at the salon where Fabia works as a hairdresser, both in the film and in her everyday life.

convincing from a purely visual point of view (figure I6.2). While Bibi's lifestyle was highly unconventional and her material circumstances were precarious, Fabia led a relatively stable life, maintaining an almost bourgeois existence with her husband in their own house in a residential suburb of São Paulo.

Although this contrast is not underlined in the film in an explicit manner, there was also an important difference in the way that they respectively related to their sexuality: both were biologically male, but whereas Bibi had moved on from becoming aware as a teenager that she was a sexually gay man, Fabia had felt from a very early age that she was a female person trapped inside a male body. Despite this difference, both Bibi and Fabia might be referred to by other Brazilians as travesti, though there is considerable controversy, both politically and academically, about the precise meaning of this term. ${ }^{6}$

From his own account of the process, it would seem that Sjöberg exercised rather more directorial control than Rouch (or at least more than Rouch generally liked to confess). At the outset, Sjöberg agreed with Bibi and Fabia that the film should not deal with such high-profile and already much discussed issues as police harassment or AIDS, but rather should focus on the impact on the transgendered people of low-key, day-to-day prejudice. Within this general framework, Bibi and Fabia initially had complete freedom to come up with ideas for scenes based on their own personal experiences. 
Sjöberg also sometimes asked them to develop scenes that were not based directly on their own lives but which would provide an opportunity to tackle issues or situations that had arisen in the lives of other transgendered people whom he had interviewed for his research.

However, Sjöberg was also concerned that the various scenes should hang together within a beginning-middle-end narrative structure, and as the filming proceeded, the more this tended to restrict the scenes that came to be filmed. Other considerations were more ethical: Sjöberg undertook never to push Bibi and Fabia to act out anything that they did not want to or which they would later come to regret. He also assumed responsibility for ensuring that it was made clear that anything that occurred in the film which was illegal, or which cast the film characters in an unflattering light, was entirely fictional and did not pertain to them in their normal lives outside the film.

Just as Rouch does at the beginning of La Pyramide humaine, Sjöberg begins Transfiction with a sort of reflexive prelude in which he is shown explaining the nature of the ethnofictional approach to his principal protagonists. The other minor characters and those playing them are then introduced one by one, supported in most cases by a shot of them discussing with Bibi or Fabia how precisely they should handle the scene in which they appear. Some of the people playing the minor roles were friends of Bibi and Fabia from the transgendered community, while others were Sjöberg's friends.

This prelude also includes an important sequence in which the principal protagonists discuss the relationship between themselves in real life and the roles that they play in the film. Bibi says confidently that while Zilda and she are definitely different people, she has no difficulty in playing this character, thereby suggesting that they have at least some elements of experience in common. Fabia's response is more complex: she suggests that she is using the fictional character of Meg as a sort of protection against acknowledging the fact that she and Meg are really one and the same person, and that the painful issues that Meg confronts in the film are also ones that she needs to confront in her own life. This comment reveals that for her, the making of the film represented an opportunity not merely to make known the prejudice encountered by transgendered people in São Paulo, but also to engage in a form of therapy through living out the personal traumas that she had suffered as a child on account of her sexuality.

Despite all this initial reflexivity about the making of the film, the performances are so thoroughly engaging that one soon forgets that the narrative is entirely fictional. The main body of film begins with a scene set in Meg's beauty salon in which she is touching up Zilda's make-up and it is established that they are friends. It then presents a series of scenes from their respective lives. Zilda goes for a stroll in a red-light district, albeit by day, with Hanah, a fellow sex worker, and they discuss in ribald terms how 
difficult their business is becoming now that they are getting older. Later, we see Zilda applying to rent an apartment and then for a job, unsuccessfully in both cases. In between these two scenes, we even see her in her role as a sex-worker entertaining a client, though the light is switched off and the narrative moves away before any serious action begins.

These scenes of Zilda are intercut with various scenes featuring Meg and her husband, Eduardo, a character played not by her real-life husband, but by Carlos, a neighbour and close friend since childhood. Meg is an altogether more disturbed character than the happy-go-lucky Zilda. She remains troubled by the traumas that she suffered as a child when she was bullied at school on account of her effeminate appearance, an experience to which the film returns several times in the form of flashbacks. In order to film these scenes, Sjöberg returned with Fabia to the same physical locations where she had originally suffered these traumatic experiences, including her former school and the deserted street where she once had to run away from a gang of boys who were threatening to beat her up. At various points, the stories of the two main characters intersect: a third of the way through, Zilda helps Meg to inject her breasts with silicon, and at the end of the film, Zilda returns to the salon to tell Meg the happy ending of her part of the story, namely, that one of her clients, a shy Frenchman, has asked her to go to live with him in Paris. She is then seen setting off for the airport, while Meg is left still worrying about her childhood experiences.

Finally, the film vouchsafes Meg a happy ending too, though one that requires a return to profilmic reality to achieve. From behind the camera, Sjöberg asks her how they should end the film, and Meg, now in her real persona as Fabia, suggests that she should return to her house and give her husband some flowers. This she duly does and then some further reflexive moments wrap the film up: Sjöberg thanks Bibi outside the salon, and then shares a glass of wine with Fabia and Carlos, the person who plays her husband in the film. Finally, as the credits roll, Sjöberg himself is shown in the salon as he is gradually transformed from a rough and bearded hetero man into a gleaming travesti, with shiny red lips and a brunette wig.

In and around this central story, Transfiction is given a certain aesthetic 'feel' by the authorial strategies that Sjöberg adopted in shooting and editing. Following Rouch's example, Sjöberg shot most of the film as if it were a cinéma-vérité documentary, using long unbroken takes whenever possible. However, in order to keep the fantasy elements firmly anchored in the real world of contemporary São Paulo, the ethnofictional story is discreetly punctuated at various points with brief snatches of contingent reality footage entirely unconnected with the central story - establishment shots of crowds on the streets, anonymous passing traffic, prostitutes touting for business at night, a homeless street kid wandering by the side of the road. 
Sjöberg supplements these classical 'reality effects' with another kind of effect that is their polar opposite, and which is based on a sort of double bluff. This takes the form of a number of establishing shots of the city in which the camera waves around in an unstable manner, with crash zooms and tilted horizons. By including these shots, which he executed in this way entirely intentionally, Sjöberg's aim was to enhance the general sense of authenticity of the film by imitating the aesthetic of a handheld camera such as one might find in an early cinéma-vérité documentary.

In the shot-sequence in which Zilda imagines herself in Paris, the waving around of the camera becomes even more extravagant. Shot in Paris itself, the camera pans up rockily from a couple of blurred tricolor flags to zoom in on the Eiffel Tower before then circling around it and burning out in a burst of sunlight beyond. The aesthetic of this shot is so unrealistic that it could not be mistaken for the work of even the most incompetent of cinéma-vérité camerapersons. Rather the idea here is to evoke the dream-like quality of Zilda's fantasy of going Paris.

Once in the edit suite, Sjöberg superimposed on the cinéma-vérité visual aesthetic various forms of music that reference the cultural tropes through which the protagonists approached both their real life and their performances, in much the same manner as Rouch superimposed the high-life hit Jaguar at various points on his ethnofiction of the same name. ${ }^{7}$ Since both Bibi and Fabia had been greatly influenced by Brazilian television soap operas, Sjöberg uses music of the kind associated with these works at all the major transition points between scenes. Music is also used at various points to suggest the place of travestis in the Brazilian collective imaginary, which, interestingly, is rather ambiguous: they are seen as the inhabitants of a dangerous and risky world but one that perhaps even the straightest person might be tempted to enter. This is achieved through a number of returns to unstable handheld close-up shots of Claudia Wonder, a well-known travesti nightclub singer in a long white wig, bandanna and extravagant lipstick, performing a song with suggestive lyrics:

travesti in my body/travesti in your bed ...

travesti of your love/travesti of your whip ...

Behind the ironic and light-hearted soap-opera aesthetic style, Transfiction offers a number of serious insights into the circumstances of transgendered people in São Paulo. Perhaps the most important of these is that due to everyday prejudices, many transgendered people can find themselves obliged to work in prostitution simply because few other jobs are open to them. But what is particularly valuable about the film specifically as an ethnographic work is that transgendered prostitution is presented in an original and fresh 
way, as the sex workers themselves see it, that is, not as a sordid and shameful activity, but rather as an entirely normal, even skilful service that can make shy people happy. This may be a controversial point of view, but this is clearly how Zilda/Bibi see her/their metier.

Much the same could be said of Zilda's happy ending: in the real world, the chances of a transgendered sex worker being whisked off to Paris by one of their clients must surely be remote, but in this sequence, in the best traditions of the Rouchian ethnofictional approach, what we are offered is not the description of reality as such, but the acting out of Zilda/Bibi's fantasy life. And that, as Jean Rouch would surely have said, is just as interesting from an ethnographic point of view as a sober account of the facts and figures about transgendered prostitution in São Paulo today.

There were also a number of other advantages to the adoption of an ethnofictional approach in this particular case. Many of the scenes in Transfiction would have been impossible to film in a conventional documentary manner, be it for practical or ethical reasons, while the scene in which Zilda injects Meg's breasts with silicon shows what is, in reality, a completely illegal activity. But there is also a more subtle quality to this film that has nothing to do with ethics, logistics or legality as such, but rather with a sort of emotional texture that is only very rarely present in a straightforwardly factual documentary. This applies particularly to the scenes involving the character of Meg and the support that she receives from her on-screen husband in coming to terms with her transgendered identity. It is difficult to imagine that the loving, supportive intimacy of their relationship could be captured on film unless, paradoxically, the characters were not merely ignoring the presence of the cameraperson, as they would be doing in a documentary, but rather were pretending that he was not there at all, as in this ethnofiction.

Although Transfiction is manifestly a fiction, I would have no hesitation in classifying it as an ethnographic film on the grounds that it is based on extended prior ethnographic research, communicates very effectively the subjects' point of view and 'the hold that life has' on them, as well as having a great deal to say about the connections between practices, ideas and relations in the broader life-world of transgendered people in São Paulo. It also respects the norms of contemporary ethnographic research ethics in that it involved close collaboration with the subjects at all stages of the production. Although Fabia and Bibi were not present in the edit suite, they approved the final version of the film before it was screened publicly anywhere else. Moreover, if we can accept Sjöberg at his word, both protagonists regarded the making of the film as a positive experience: indeed, a year after the filming was completed, Fabia told him that it was the most effective therapy that she had ever undergone. 
Yet another 'way of doing' ethnographic film authorship in a participatory manner involves foregrounding the personal experience of the ethnographer as they take part in the life of the subjects during fieldwork, and using this as the vehicle through which the multiple interconnections between the practices, ideas and relations of the subjects may be explored. There have been a number of interesting examples of films of this kind in recent years, ranging from those in which the ethnographer is a leading character in a film that is directed and technically realised by others, through those in which the ethnographer is both a character and the director but relies on others to carry out the technical roles, to those in which the ethnographer does everything, participating in the action, directing the film, as well as carrying out all the technical roles.

An interesting example of the first case, in which the ethnographer appears as a leading character in a film directed by others, is Koriam's Law and the Dead who Govern, released in 2005. This film concerns the ideas and practices of the Kivung Association, a religious and political movement based in and around Pomio, an administrative district on the eastern shore of the island of New Britain, Papua New Guinea. It was based on the long-term fieldwork of the Australian anthropologist Andrew Lattas and was jointly directed by Gary Kildea and Andrea Simon.

This film was originally conceived as part of a US television series on millenarian religious movements. This was produced by Simon, who recruited Kildea to the project on account of his long experience as a cinematographer working in Papua New Guinea. When the television series ran into difficulty, Kildea asked Simon if he could use the 52 hours of rushes to cut a somewhat different kind of film. Simon agreed, and Koriam's Law, with a running time of IIo minutes, is the result. Although Simon and Kildea jointly produced and directed this film, it was Kildea who carried out the editing as well as the shooting. ${ }^{8}$

Founded in 1964 by Michael Koriam Urekit, a local leader, the Kivung Association movement is based on the belief, widely held in Melanesia, that material well-being depends on the establishment of good relations with the dead, who are ever-present in everyday life even though they remain invisible. Koriam gave this idea a political edge by proposing that the disparity in wealth between Whites and Melanesians was due to the fact that the former had somehow managed to establish an inside track with the dead and were siphoning off the material wealth offered by the latter for their exclusive use. The aim of the movement, at least as originally formulated, was to develop ritual procedures that would allow its members to establish their own relationship with the dead, bypassing the local Catholic mission, which they saw as being complicit in the Whites' secretive insider 
dealings with the dead. As a number of subjects explain in the film, in their view any attempt to achieve material well-being through business or other economic development activities is a waste of time: what really matters is getting hold of the esoteric knowledge that is required to persuade the dead to provide this wealth.

Koriam's Law is constructed around a series of dialogues between Andrew Lattas and leading members of the Kivung Association movement. But the film is very much more than the record of an academic research project in that it raises a series of questions about postcolonial social and political relations, as well as about the disjunctions between local and global systems of religious belief. Underlying the dialogues between Lattas and his interlocutors, there is a strong, even if mostly unspoken tension, namely, that while Lattas is trying to find out more about the Kivung Association, the Melanesians are trying to unlock the secret of the Whites' special relationship with the dead, all the while believing that Lattas, as a White, must himself hold this secret knowledge but is unwilling to share it with them.

In the early part of the film, these dialogical exchanges are intercut with a series of scenes in which people in the village of Matong are shown practising the ritual procedures that the Kivung Association has developed in order to establish its own direct relationship with the dead. These ritual procedures draw in part on indigenous practices, notably in offering food to the dead as a means of encouraging eventual reciprocity. But they have also been modelled in part on the religious and administrative practices of the Whites: the association members reason that as these procedures have apparently been effective in securing material rewards from the dead for the Whites, they should also work for them. One of the most widespread involves paying money into a glass jar, known as a 'Novena bottle', every time one has committed a sin or other form of moral infraction. At the same time, a paper ledger, referred to as a 'report', is kept of these payments, and when the Novena bottle is full, it is added in with the money and offered to the dead. As Lattas comments, whereas in the past the people of Pomio communicated with the dead through dreams or by becoming possessed, now they do so by means of these 'reports' and donations of money. The money itself is used in part to pay for more food offerings to the dead, while part is donated to the Kivung Association itself (figure I6.3, left).

A particularly telling scene takes place close to the cemetery: we do not see into the cemetery itself, but one of Lattas's interlocutors introduces him to a noticeboard where the names of the dead are listed, as if on a European war memorial. The dead include a certain 'Australia', an anonymous Australian who died of disease during the Second World War. As his relatives never came to collect his remains, the people of Pomio have adopted him as one of their dead, and have been 'feeding' him in the expectation that he will return the favour. Eventually, the Kivung Association people 

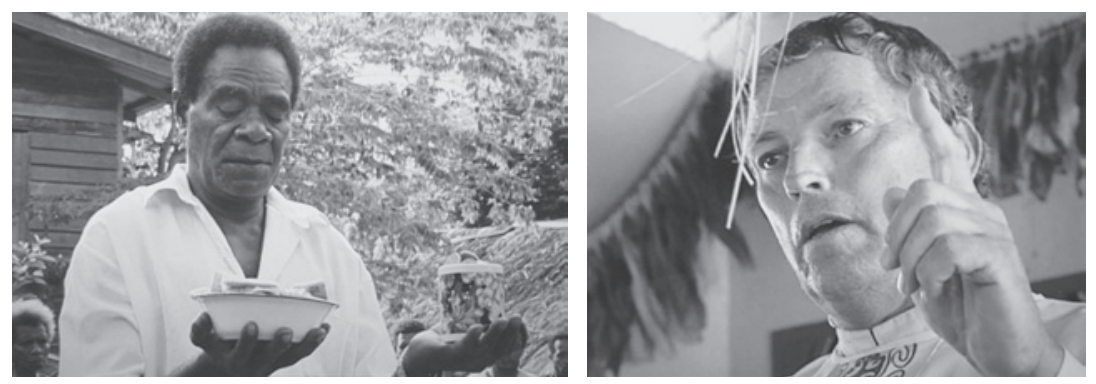

I6.3 Koriam's Law and the Dead Who Govern (2005). Left, the people of Pomio, New Britain, Papua New Guinea, have developed their own ceremony, modelled on Catholic liturgy, in which they offer food and money to the dead. But the Catholic priest, right, urges them to use these resources to help their living children instead.

believe, the dead will be resurrected and the cemetery will be transformed into a modern city, where Whites and Blacks will live in harmony and on equal terms.

About a third of the way into the film, there is something of a change of gear. This begins with the arrival by boat of an itinerant Catholic priest, a European who speaks both English and pidgin with a German accent. He greets the film-makers in a friendly manner and explains that he has come to conduct a Christmas Day mass. Having changed into his full ritual robes from the shorts and baseball cap in which he arrived, the priest first talks to his Melanesian congregation about events that happened in Palestine two millennia ago and then offers them the opportunity to eat the body of a man who lived at that time. In other words, he discusses events described in the Bible and offers them Holy Communion. In the context of the film, however, his words and ritual procedures seem no more well-founded in any rational apperception of the world than the Kivung practices that we have seen immediately beforehand. In his sermon, he then rails against the collection of Novena money for the dead: he urges his congregation to use this money to ensure the health of their children instead (figure I6.3, right). At face value, this might seem like an entirely positive humane proposition, but having been made aware of the Kivung Association's beliefs, we can now understand how his homily might be interpreted as no more than a devious stratagem intended to discourage Pomio people from building the relationships with the dead that are required to unlock material well-being.

The action of the film then moves to the village of Salel, where the headquarters of the Kivung Association are located. Here, we are introduced to an eloquent and seemingly well-educated man who describes himself 
as a local 'governor' operating in the 'political realm' but who is still guided by the spiritual beliefs of the Kivung Association. The views of the dead are communicated to him by a woman who has been possessed by the spirit of her son, named Jo, who died during a miscarriage, but who is believed to be the spiritual son of one of the founders of the movement. The governor describes Jo as 'a sort of contemporary Melanesian version of Jesus'.

The governor then explains that although some people have attempted to discredit the Association by calling it a 'cargo cult', it does not have anything to do with waiting for cargo, at least not now. Instead, it is focused on securing development aid through the government and indeed has been successful in getting funding for a number of local schools and copra plantations. This section of the film culminates in an elaborate celebration of the thirty-fourth anniversary of the foundation of the Kivung movement, with much speechifying, choral singing and traditional dances. This is attended by members of the national parliament who have flown in especially for the occasion, testifying to the increasing political weight of the Association. It may not be a cargo cult in the classical anthropological sense, but we see that the Association has clearly been very successful in attracting wealth from elsewhere.

Finally, for the last ten minutes, the film returns to Matong and to the dialogue between Andrew Lattas and Peter Avarea, one his principal interlocutors. In a moving passage, Peter, who is disabled, says that he believes that the Kivung Association will prosper, and that in due course of time it will arrange for his legs to be made good again. He adds that although some people will think that he has told Lattas too much, he himself believes that Melanesians should not be afraid to speak out. As the sun is hot, they agree to take a break, and the film concludes with a final valedictory image of the sea, allowing us a calm moment of reflection before the credits break in, dispersing the powerful spell that the film has cast.

It has to be acknowledged that there is a certain stylistic unevenness in this film, which can perhaps be traced to the fact that it had two directors and was originally conceived as a television programme. Moreover, some viewers have felt that the editing is not as effective as it might have been: although the Kivung Association's beliefs and organisational arrangements clearly pose a challenge to European ways of thinking, some critics have suggested that they could nevertheless have been presented in a clearer fashion. But notwithstanding these possible limitations, Koriam's Law offers an interesting model of the possibilities that can arise when an ethnographic film-making project is based upon a combination of close collaborative relationships with the subjects achieved through long-term ethnographic fieldwork and cinematographic craft skills of the highest order. The particular strength of the film lies in the fact that, paradoxically, it takes advantage of 
the materiality of the medium of film to convince the viewer of the reality of the immaterial world of the dead for the subjects of the film. It may be not be possible for an irreligious Western viewer to believe, as the members of the Kivung Association do, that the dead really do govern the lives of the living, but Koriam's Law certainly encourages us - to use the turn of phrase coined by Jean Rouch - to believe in their beliefs.

\section{PARTICIPATORY FILM-MAKING THROUgh LONG-TERM PERSONAL ENGAGEMENT: THE HAMAR TRILOGY AND DUKA'S DILEMMA}

In the case of Koriam's Law, though the ethnographer's long-standing relationship to the subjects provides the main channel through which the subject matter of the film is explored, Andrew Lattas himself did not direct it. Recent years have seen a number of ethnographic films that are similarly reflexive and based on a long-standing relationship with the subjects, but which have also been directed by the ethnographer.

A particularly good example is Duka's Dilemma, which was shot in $200 \mathrm{I}$ and released in 2002. This film was directed by the anthropologist Jean Lydall and was based on her close relationship with the Hamar people of southern Ethiopia, whose way of life is based on a combination of cattle herding and millet agriculture. At the time of filming, this relationship reached back some three decades to I970 when, together with her husband, Ivo Strecker, Lydall first carried out fieldwork with the Hamar. Early on in that fieldwork, in I97I, Lydall and Strecker had advised Robert Gardner on the making of Rivers of Sand, but they had been deeply dissatisfied with the result. They took particular exception to what they considered to be the simplistic way in which Gardner had represented Hamar gender relationships as being based on the oppression of 'meek overworked' women by 'vain indolent' men. It was in order to counter Gardner's filmic representation of the Hamar that both Lydall and Strecker later took up film-making themselves. $^{9}$

After working with Strecker on two films for the German television station SWF in I982-83, Lydall then collaborated with the anthropologically trained director Joanna Head between I990 and I994 to make a trilogy of films about the life experiences of Hamar women for the BBC Television series, Under the Sun. Although Duka's Dilemma is somewhat different from the BBC trilogy in terms of cinematographic praxis, there are many elements of continuity with regard to subject matter. In effect then, Duka's Dilemma constitutes the fourth instalment in a quartet of films about Hamar women's lives that interconnect and complement one another at a number of different levels. Certainly, the viewing of Duka's Dilemma is greatly enriched by prior 

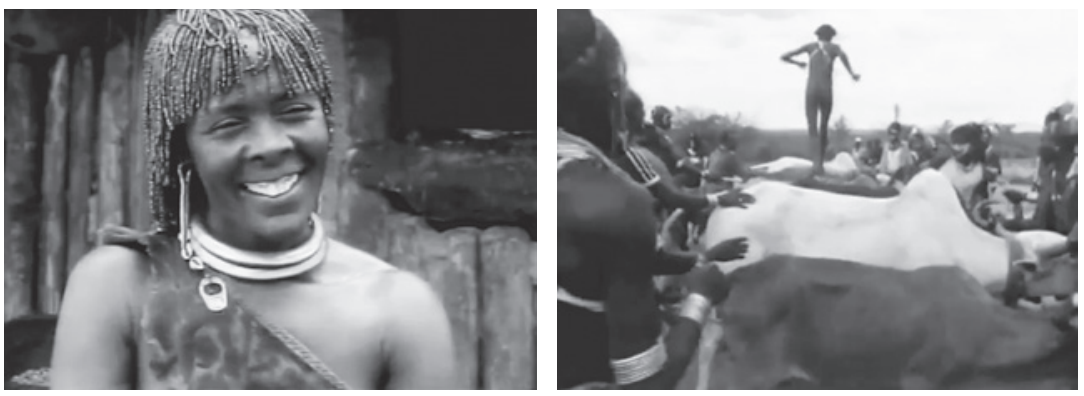

I6.4 The Hamar trilogy, Under the Sun strand. In The Women Who Smile (I990), left, and Two Girls Go Hunting (I99I), the focus is on the lives of women. Right, in the third part, Our Way of Loving (I994), it also embraces other themes, including the 'leap across the cattle', the male initiation ceremony.

acquaintance with the Under the Sun trilogy. I therefore consider it here in that broader context.

In practical terms, the first film in the BBC trilogy, The Women Who Smile, was directly inspired by the prior example of Melissa Llewelyn-Davies's films about the Maasai. This was no coincidence since Joanna Head, the director, had started her film-making career in the early I980s working as a researcher on the Worlds Apart series that Llewelyn-Davies co-produced out of BBC Bristol with Chris Curling. ${ }^{10}$ As with many of Llewelyn-Davies's Maasai films, The Women Who Smile is constructed around a series of intimate conversational interviews with a number of key female interlocutors: an unmarried woman in her 20 still living in her father's house, a recently widowed but still young woman with four small children and, finally, an older woman with eight surviving children (a further ten having died in infancy), who had recently persuaded her husband to take a second wife. Although the second film in the trilogy, Two Girls Go Hunting, also remained closely focused on female experience as it followed two girls through the process of getting married (the metaphorical 'hunting' referred to in the title), the third film, Our Way of Loving, covered a somewhat broader range of themes, including some scenes of contact with the outside world, a funeral and some tense bridewealth negotiations. It culminated in an extended sequence about the 'leap across the cattle', the rite of passage that young men have to complete before they are allowed to marry (figure I6.4). Throughout all three films, one is very aware of Lydall's presence since we frequently hear her voice in the conversational exchanges with the subjects.

The general picture that emerges from this trilogy of BBC films suggests that while Robert Gardner may have indulged in some ethnographically erroneous symbolic juxtapositions and exaggerated both the shiftlessness 
of Hamar men and the lack of the agency of Hamar women in managing their lives, he was not entirely wrong in so far as the general tenor of gender relations in their society is concerned. For, as the female interlocutors explain to Lydall with candour and charm, and more with an air of regret than with bitterness, their lives are highly restricted compared to those of men. Whereas a boy is regarded as a 'person' as soon as he is a born, a girl child is regarded as no more than a 'guest' in her own home since she is already thought to 'belong' to her future husband. Having enjoyed certain freedoms as a girl, marriage is a time of sadness for the bride, for not only is she separated from her family and obliged to go and live in the house of a man whom she has never met, nor played any part in choosing, but that house becomes a 'trap' from which there is no escape. Although marriage for a woman may be metaphorically compared to hunting among the Hamar, there is no 'glory song' attached to it, as there is when a young man brings back his first major kill. On the contrary, marriage for a woman entails a great deal of hard labour: looking after children, preparing food, tending livestock, working in the fields, cleaning the house and kraal, and being ever attentive to her husband's beck and call. Only a mature woman, who has many children and some in-married daughters-in-law to help her with the chores, and who, in the ideal case, can persuade her husband to take a second wife to share the burden, can gain a significant measure of relief from this workload.

Most disturbing of all in these testimonies is the recurrent reference to the beatings that husbands seemingly routinely inflict on their wives. Both women and men refer to these beatings as if they were an inevitable fact of life that one is obliged to accept if one is a woman and expected to administer if one is a man. What is particularly unsettling is that these beatings are often spoken about, particularly by the men but even sometimes by women, by subjects who are grinning broadly as they do so. At first, one is inclined to think that this is a sign of embarrassment because the subjects know that Lydall will not approve of the practice. But in the third film of the trilogy, as suggested by the title, Our Way of Loving, it becomes evident that if the Hamar show a certain embarrassment in talking about these beatings, it is not on account of the admission of intergender violence, or at least not only so, but also because beatings can be associated with the arousal of erotic passions.

This is certainly suggested by the preliminary rituals associated with the 'leap across the cattle' male initiation ceremony that features in the final extended sequence of Our Way of Loving. Prior to the main ceremony, a relative of the initiate, who has himself already been initiated, is expected to arm himself with a fistful of thin switches and to whip any woman that he comes across. In Rivers of Sand, Robert Gardner presents this whipping as a symbolic expression of Hamar men's violence against women, suggesting, 
through editorial juxtapositioning, that there is a parallel between the whipping of women and the treatment meted out to donkeys or cattle. ${ }^{11}$ Judging by the way this practice is presented in Our Way of Loving, this is entirely misconceived. For those who come to be whipped are not random women whom the initiand's relative just happens to encounter, but rather women and girls who had previously been the initiand's actual or potential lovers but whom he should now foreswear - at least in principle. Immediately prior to his leap across the cattle, these former lovers present themselves to the initiand's relative of their own free will and in an extrovert manner, some blowing horns and others whistles, noisily and actively provoke him into whipping them. Afterwards, they will wear the deep and permanent scars that his whip will make across their backs with pride, as a symbol of the intensity of their love for the initiand. In due course of time, the initiand may give them gifts in exchange for this expression of love for him.

When Jean Lydall came to make Duka's Dilemma and was free, as the director, to adopt the practical approach that she most preferred, she chose not to follow the television model used in the films that she had made with Joanna Head, but rather one that was more akin to the approach that David and Judith MacDougall had developed in their work in East Africa in the I970s. ${ }^{12}$

The most immediate practical consequence of this change of praxis was that rather than being made by a professional television crew, Duka's Dilemma was shot by Lydall's daughter, Kaira Strecker, who had trained a camerawoman. Kaira also recorded the sound and later did the editing. As a child, Kaira had spent several years living with her parents while they were engaged in fieldwork among the Hamar, and although by the time of filming her command was a little rusty, she could therefore speak their language. Not only did she know the Hamar, but they knew her: indeed, in the opening sequence Duka, the principal subject, addresses her as 'little sister' and urges her to film well. Kaira brought her 3-year-old son, Tammo, to show to Duka, and we see him at various points in the film, playing with Hamar children. We also see Kaira herself in the final sequence while the family's Land Rover appears in the background of several shots. Such elements of reflexivity, while not entirely ruled out by Joanna Head, were kept to a minimum in the BBC films.

Conversational exchanges between Lydall and the subjects are central to Duka's Dilemma just as they had been in the BBC films, but in general they are more informal. These exchanges mostly take place while the subject is engaged in some other activity, a strategy that Head had sought rather to avoid. A more striking difference concerns the voice-over commentary. During the production of the BBC films, Lydall had suggested that she should speak the commentary herself, despite her reservations about the quality of her own voice, so that the voice-over would link up with her 
voice as it is heard recurrently in conversation with the subjects. But the BBC producers had opted instead to use professional voice-artists with the usual aesthetic effect of distancing and objectifying the subjects, notwithstanding the fact that the voice-artists were all women and, in one case, had what was supposedly an African accent. Their smooth professional voices punctuate the BBC films at regular intervals from beginning to end, whereas in Duka's Dilemma, other than the brief commentary spoken in Hamar by Kaira near the beginning of the film, there is no voice-over at all. When contextualising information is necessary, it is delivered through intertitle cards instead.

The eponymous principal subject of Duka's Dilemma is a woman whom Lydall had known since she was a child. Indeed, Duka represents a strong thread of continuity running through all four films of the quartet: she was the unmarried woman in The Women Who Smile, then one of the two women who get married in Two Girls Go Hunting, and she also appears frequently in Our Way of Loving, by which time she was a married woman with two small children. As Duka's Dilemma opens, some eight years on from the previous film, Duka is in her late 30 and mother to five children. We discover that she is in what could perhaps be more exactly described as a predicament rather than a dilemma (since there does not appear to be much of a choice involved): as she explains in the opening sequence, she had recently been sick for a prolonged period and Sago, her husband, had taken advantage of her indisposition to take a second, much younger wife, Boro, whom he has married surreptitiously 'in the bush'. He has done so much to the disapproval of his mother, Sagonda, a widow, and a lively and feisty character who had also appeared in the earlier films.

The narrative of Duka's Dilemma consists, essentially, of following the social processes through which these four characters negotiate the consequences of Boro's sudden and, to Duka, disturbing arrival. Audiences familiar with the earlier films will know that in Hamar society, co-wives are usually strangers to one another at first since they will often have come from different villages, but that, over time, they can be an important source of mutual support in fulfilling their many domestic obligations and, as necessary, standing up to their husbands. Similarly, the relationship between in-married women and their mothers-in-law, who also generally begin as complete strangers to one another, can also become close and mutually supportive.

However, at the beginning of Duka's Dilemma, the relationship between Duka and Boro is poor: although Duka seeks to be generous and welcoming, and presents her husband's decision to marry again as a desire to provide her with additional help in looking after the children - indeed even as an arrangement that she herself had decided upon - Duka also sees Boro as a rival (figure I6.5, left). Boro herself is very hostile and bad-tempered, not 

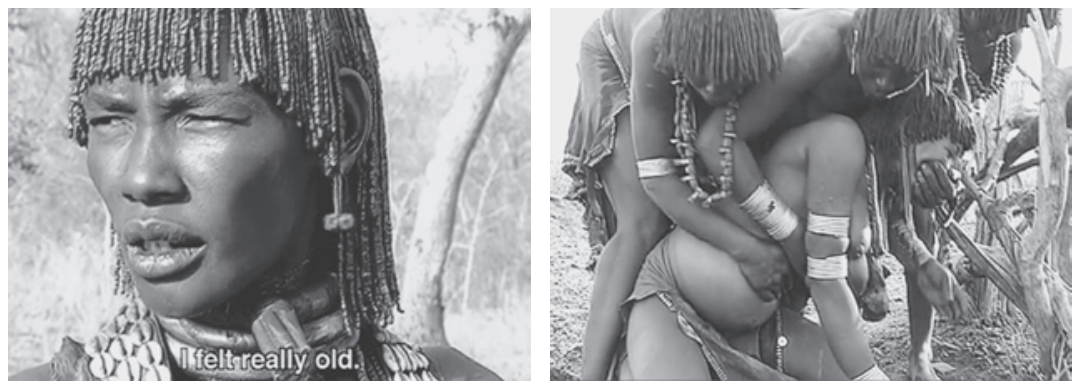

I6.5 Duka's Dilemma (200I). Left, when Duka's husband takes a much younger second wife, Boro, initially she feels threatened. But after she helps Boro through the process of giving birth, right, the two wives become mutually supportive.

only towards Duka, but also towards their common mother-in-law Sagonda, whom she considers, with good reason, to be on Duka's side. Meanwhile, Sago remains aloof from the whole process, contenting himself with shouting instructions at his wives and his mother from outside the family kraal.

Duka herself surmises that the situation is made worse by the fact that Boro has not yet had any children, and that as soon as she does have a child of her own she will be much happier. This comment anticipates a particularly powerful and dynamic scene in which Boro gives birth and during which she is energetically assisted by both Duka and Sagonda, and one or two other women from the village: as women go to live in their husband's village after marriage among the Hamar, Boro's own mother and sisters are far away (figure I6.5, right). This scene is very well and sensitively shot by Kaira but spares little detail, and as such, has been criticised for being far too intrusive. But Lydall has robustly defended the scene on the grounds that on the basis of her long-standing relationship with the Hamar, she was confident that the subjects would find it entirely acceptable to show the process of birthing so explicitly, and moreover, in the film itself, they specifically give Kaira permission to film. What is certainly the case is that Duka's prediction is proved right, and following the birth, Boro becomes much happier with her lot. The relationship between the co-wives becomes mutually supportive, with Duka working in Boro's fields while she is recovering from the birth and even breastfeeding her baby. Later in the film, when Duka gives birth to her own son, Boro provides her with food and drink, while Duka is shown breastfeeding both babies simultaneously.

A secondary theme running through the film concerns the tension between Sagonda and Sago, her son. Sagonda feels that she is given insufficient respect as a widow and deserves to have her own house, built for her by 
Sago. She takes advantage of the gathering of male elders for the naming ceremony for Duka's baby (and possibly of the presence of the camera as well) to threaten to take herself off to the local town and 'sell her vagina'. Eventually the matter is resolved by a council of elders, who find for Sagonda, thereby demonstrating that contrary to the general trend, women sometimes can prevail in Hamar society, though usually only if they are senior women. The film then builds to a 'happy ending': Sagonda's house is built by a work-party organised by Sago, while the final sequence consists of a tranquil scene of both Duka and Boro together with Sago and their children, at home in their kraal.

In an epilogue, Kaira appears on screen and asks Duka if there is anything else that she would like to say. Duka replies that she has nothing to add except the hope that Kaira will show the film to the father of her son and to all her friends, and that, as a result, people will understand the Hamar and like them. Whether the film is successful in this last regard is, of course, necessarily moot, but what the film certainly does show is the benefit of a participatory praxis based on a long-term relationship between ethnographer and subjects.

\section{PARTICIPATORY FILM-MAKING AS 'SENSORY APPRENTICESHIP': KALANDA}

In the final example considered here, the ethnographer's relationship to the subjects is again the vehicle through which the themes of the film are explored, but in this case the ethnographer not only acted as director of the film but also carried out the principal technical roles as well. A very effective example of this particular mode of participatory praxis is Descending with Angels, which was shot, directed and edited by Christian Suhr and released in 2013. This film was based on eighteen months of field research in Aarhuus in Denmark, conducted by Suhr himself, among the Salafi Islamic community of the city and in the local psychiatric hospital. The film compares and contrasts Islamic and secular forms of healing what one might broadly call mental tribulation, which is interpreted as the effects of spirit possession by the Islamic community and as a mental illness by the psychiatrists. However, although this film is very well made, both from a technical and editorial point of view, it has recently been the subject of a book-length commentary by Suhr himself, published in the same series as this one, and this provides a much more informed analysis of the film than anything that I could offer here. ${ }^{13}$

I therefore turn instead to a more recent film, which was released in 2015 when the maker was still a doctoral student at the University of Manchester. Whereas the praxis of Suhr's film is based on relatively 
conventional observational realism, the ethnographer-film-maker in this case took advantage of recent developments in digital technology to be more aesthetically experimental. In this sense, it constitutes an interesting attempt to combine the 'sensorial' approach of the Harvard Sensory Ethnography Lab with a more participatory praxis.

The ethnographer-film-maker in question was Lorenzo Ferrarini, an Italian, who carried out doctoral fieldwork over the course of two years in the region west of Bobo-Dioulasso, in southwestern Burkina Faso in 2OII-I2. The principal focus of this research was donsoya, a body of esoteric beliefs and practices associated with hunting found in various forms throughout the Mande cultural area of West Africa. In the course of this fieldwork, Ferrarini shot the material for what would eventually become an hour-long documentary, Kalanda - The Knowledge of the Bush. This is structured around his own initiation into donsoya. ${ }^{14}$

As a body of knowledge, donsoya involves not only hunting skills per se, such as an awareness of the habits of potential prey and how to walk through the forest with minimal noise, but also a knowledge of the magical procedures deemed necessary to offer protection to hunters. In order to achieve this protection, a hunter needs to know how to make up the amulets containing sacred texts from the Koran that he will wear while hunting. He also needs to know how to prepare certain powders that he should apply both to his own body and to his gun, as well as to his prey after it has been killed. In addition to this more technical knowledge, Ferrarini also learned more generally about the work of donso hunters as diviners and healers, and about their relationships with the musicians who play a remarkable harp-like instrument known locally as n'goni.

This knowledge is passed on to Ferrarini in Kalanda as a series of lessons from a master-hunter, Adama Sogo Traoré. Sitting beneath a tree in his traditional mud-walled compound, Traoré is framed in mid-shot, attired in various elegant boubous as the film proceeds. Speaking eloquently in Jula, the local trade language, he looks down at Ferrarini who is both literally and metaphorically sitting at his feet behind the camera (figure I6.6, left). The teacher frequently sends Ferrarini off to be instructed by others in certain specific aspects of donsoya and we see him out hunting in the bush by day, collecting medicinal plants, visiting a man who washes his gun and another who makes amulets, as well as learning from a musician about the praise songs that he sings to the hunters. The musician also shows Ferrarini the extraordinary shirt that he wears, covered with mirrors, cowrie shells and fetishes in order to protect himself against evil-doers. After each of these episodes, Ferrarini returns to sit at Adama's feet.

Ferrarini refers to his enskilment in donsoya as a 'sensory apprenticeship' since the sensory dimension is as important as the linguistic. When sent off by Adama to learn from a younger hunter, Lasseni, Ferrarini does not just 

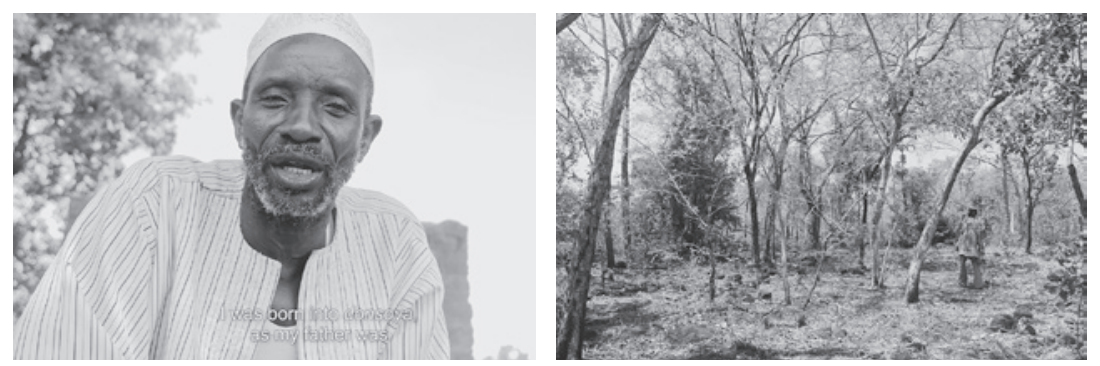

I6.6 Kalanda (20I5). Left, sitting at the feet of the master-hunter, Adama Sogo Traoré, the film-maker is instructed about donsoya; right, while learning to hunt, he used an extreme wide-angle lens to emphasise his initial perceptual frustration.

interview him, but accompanies him on a hunt. In shooting the sequence showing this hunt, Ferrarini broke with conventional observational realist norms in order to emphasise certain aspects of this learning experience: thus, for example, he held the camera much lower than level of his eyes, even though this was not strictly realistic, since he wanted to emphasise the sense of scanning meticulously for evidence of small game hiding under the bushes. He also used an extreme wide-angle lens, which makes it difficult for the spectator to focus on any particular detail. In this way, he hoped to communicate the sense of perceptual frustration that he himself felt when first learning to hunt (figure I6.6, right).

Since mastering the acoustic aspects of hunting is particularly important in the process of becoming an initiated donso hunter, Ferrarini also put a great deal of thought into the sound design of his film. Although much of the film consists of 'normal' synchronous sound, this was supplemented by the extensive use of wild-tracks. These were often recorded on two cardioid microphones positioned more or less at right angles to one another, sometimes in a single static position in order to record general ambient sound, while at other times they were attached a boom pole and used to capture such things as human steps moving over various different surfaces at different speeds. In the hunting sequence described, Ferrarini supplemented the synchronous ambient sound track with wild-tracks in order to communicate a sense of the process whereby the novice becomes aware of the acoustic environment.

Drawing on previous usages by the ethnographer of boxers in Chicago, Loï Waquant, and ultimately by the neurophenomenologist Francisco Varela, Ferrarini refers to his praxis in making Kalanda as 'enactive'. This 'way of doing' ethnographic film-making, as he presents it, is based on the idea that it is through immersion in the sensory world of the subjects and the 
first-hand acting out of key aspects of that life that the film-maker achieves ethnographic understanding. Also important, however, is the principle that this immersion should always involve active collaborative relationships with the subjects.

The making of Kalanda was collaborative in a number of different regards. In a precise technical sense, inspired by the example of Steven Feld's groundbreaking work among the Kaluli of Papua New Guinea, Ferrarini used sound editing software in the field to work directly with his hunter-instructor Lasseni in order to get a sense of how his recordings sounded to an experienced donso. This allowed him to distinguish recordings of a good hunter moving through the bush as compared to his own noisy beginner's movements. This then enabled him to use these sounds in the appropriate way on the soundtrack of his film.

Later, Ferrarini showed all the different chapters of his film to their subjects, not only to receive their feeback about the accuracy or significance of the material, but also to seek their approval to include that material in the final film since much of the knowledge involved was considered to be secret, and not suitable for showing to women or to men who had not been instructed in donsoya. Even since it was completed, Kalanda has continued to be a collaborative project in the sense that part of the income from sales of the film and associated photographs is systematically returned to the subjects.

An important point, however, is that the collaborative nature of Ferrarini's praxis is sewn into the very structure of the film rather than signalled in an overt manner. Indeed, compared to Koriam's Law or even Duka's Dilemma, the reflexivity of Kalanda is relatively low-key and discreet. We are aware of the ethnographer-film-maker as the initiate sitting at the feet of his teacher, and at one point in the film we see close-ups of parts of Ferrarini's body (feet, arms, back) in a series of static shots that show him washing in a protective medicinal solution. At another point, we see Lasseni watching rushes on Ferrarini's laptop. But until the final shot of the film, we never see more than a part of his body, nor do we hear his voice in voice-over commentary.

At the same time, in its extensive manipulation of sound and image, Ferrarini's praxis in Kalanda goes well beyond observation. In addition to the manipulations aimed at communicating the experience of his 'sensory apprenticeship', there are also passages of time-lapse photography, still photographs inserted into the middle of observational shots, and asynchronicity, all of which remind the viewer of the limitations of observational realism. Kalanda also goes beyond observation in its narrative structure, notably in relation to the principal structuring device of the apprentice sitting at the master's feet, who is then sent off to consult third parties. This device was 
entirely enacted for the film in the sense that the exchanges between Adama and Ferrarini were filmed after all the consultations with third parties. Once he had a rough cut of most these consultations, Ferrarini showed them to Adama and asked him for his comments so that he could link these various scenes together. Ferrarini reports that Adama performed these links 'brilliantly': only occasionally did he have to provoke Adama with questions.

Also beyond observation is the framing of the master-apprentice narrative by the two shots of Ferrarini hunting at night that open and close the film. As the film itself makes clear in a reflexive manner, these shots have been very carefully set up and lit, and, moreover, they are presented in reverse chronological order. In the opening shot, in a carefully placed pool of light in the darkness, we see a close-up of two pairs of hands, one black, holding a recently slaughtered antelope, while the other is white and is scattering powder into the antelope's eyes and wounds. This is a record of Ferrarini's first kill at night - the climax of his instruction in donsoya. However, it is not until the final shot of the film that we finally see him emerge from behind his tripod-mounted camera and set off into the darkness, along with his two donso companions, in order to make that kill. On the soundtrack, Adama's voice is heard reminding Ferrarini that when one becomes a donso, it should be a lifelong commitment, rounding off the film with the classical narrative device of a projection into the future.

If the praxis underlying Kalanda goes beyond observation in all these ways, it is also very different from the praxis of the Sensory Ethnography Lab (SEL). Like the SEL film-makers, Ferrarini uses digital technology in imaginative ways in an attempt to evoke sensory aspects of experience. Also like them, he recurs to theorists writing from a phenomenological perspective to provide an endorsement of this aspect of his praxis. But in contrast to at least some SEL film-makers, Ferrarini is not afraid to use language, both verbal and cinematographic, to make connections between ideas, actions and social relations, and his praxis is in general very much more participatory and reflexive. In this sense, he has developed a 'way of doing' ethnographic film-making that draws effectively on a range of different traditions to produce an account that is simultaneously sensory, linguistic and analytical.

What is particularly valuable, in my view, about all the films considered in this final chapter is that they are based in the first instance on a form of committed engagement with the subjects - explicitly political in the case of Tracks Across Sand, implicitly political in the case of Transfiction and Koriam's Law, more moral and personal in the case of Duka's Dilemma and Kalanda. In a variety of forms, these works offer a range of examples of how the medium of film, deployed in a participatory manner, can be used to develop a rich ethnographic account, structured by an engaging narrative, 
of the many connections between practices, ideas and relations in the social lives of their subjects. But notwithstanding the strongly collaborative ethos of these works, there is no pretence on the part of their makers that they have somehow been authored by the subjects: in all cases, the creative, intellectual and ethical responsibility for the films remain manifestly with the film-makers.

These films should not be considered models to be emulated in every particular: they are models of possibility rather than models of perfection. Nor should they form the basis for some sort of future orthodoxy. But in going beyond observation in their variously reflexive and participatory praxes, while at the same time remaining clearly authored by their makers, these films reach back to the shared anthropology of Jean Rouch while also suggesting interesting possibilities for 'ways of doing' of ethnographic film in the twenty-first century.

\section{Notes}

1 Ginsburg (2018).

2 I am grateful to Hugh Brody for his comments in December 2018 on the manuscript version of this section of the chapter.

3 See Robbins (2008), 5I-76. See also the discussion of John Marshall's later films about the Namibian San in Chapter 6, pp. I88-93.

4 See Henley (2009), 67-100.

5 In this discussion, I draw on Sjöberg's doctoral thesis (2008a), particularly pp. II4-34, and two later articles, Sjöberg (2008b; 20I8). I am grateful to Sjöberg himself for his comments on a preliminary version of this section.

6 See Sjöberg (2008a), 74-80.

7 See Henley (2009), 79-8I.

8 In a career stretching back to the I970s, Gary Kildea has been one of the leading exponents of Observational Cinema. See Crawford (2004) and Kildea (2007) for overviews of his work. See also Chapter Io, pp. 306-9.

9 See Chapter 9, pp. 260-I and Lydall (2008), 37. In writing this section, I have drawn on this article as well as on an earlier article by Lydall (I992). I have also drawn on Lydall and Strecker's jointly signed response to a favourable academic review of Gardner's film (I978).

10 For a detailed discussion of Llewelyn-Davies's films, see Chapter I2, pp. 357-68.

11 See Chapter 9, p. 270.

12 Lydall (2008), 43 ff. See Chapter 5 for a discussion of the MacDougall's East African films. Initially, Lydall had approached the BBC with a proposal, but by 2000 , the Under the Sun series had come to an end and there was very little interest in commissioning research-based ethnographic films in British television. It was this that led Lydall to initiate the film herself, though in the later stages of production, she received support from the German television station, WDR (Westdeutscher Rundfunk) and the IWF (Institut fuir den Wissenschaftlichen Film).

13 See Suhr (2019). Suhr was also involved, this time in a co-directorial role, in another good example of participatory film-making based on a long-term relationship between an ethnographer and the subjects. This was Ngat is Dead, which was filmed on Baluan, one of the Admiralty Islands, which lie off the northern coast of Papua New Guinea. Released in 2009, this film followed the Dutch anthropologist Ton Otto, the other co-director, as he returned to Baluan, where he had carried out fieldwork over many 
years, in order to attend the mortuary ceremonies of a senior man who had adopted him as a son.

14 Ferrarini also made a number of shorter films, as well as producing a substantial portfolio of photographs and audio recordings. For further details see https:// lorenzoferrarini.com. In describing the making of Kalanda, I draw on Ferrarini's own published account (2017). See also the review of the film by Steven Feld (20I6). I am grateful to Ferrarini for his comments on a draft of this section. 